Beata PRZYBYLSKA-MASZNER, Jarosław JAŃCZAK

Adam Mickiewicz University in Poznań, Poland

\title{
The priorities of the Polish presidency of the Council of the European Union - the circumstances of their selection and implementation
}

\section{Introduction}

$\mathrm{T}$ he year 2004 and Poland's accession to the European Union marked the final stage of the Euro-Atlantic stage of Poland's policy, which unquestionably dominated in its domestic and foreign relations after the collapse of communism. On the one hand, formal membership of the EU crowned longstanding efforts aimed at accession, but on the other opened a whole range of new dimensions in relations with Brussels and other member states. Involvement in EU decision-making processes generated previously absent opportunities to create common policies and express Poland's own national interests. Yet, the accelerated integration processes, coupled with new kinds of domestic and external challenges, created a politico-international environment that required considerable efficiency and responsibility in interactions.

One of the instruments illustrating these tendencies was Poland's presidency of the Council of the European Union. The six months of the presidency provided an opportunity to promote Poland's vision of integration and present its own political and economic interests in a highly ordered and perceptible manner. At the same time, it constituted a challenge of taking constructive responsibility for the common good and showing consideration for other outlooks on how to provide conceptual and political impetus to the EU. The challenge was even more difficult, as the presidency was exercised within a trio (with two other states that did not necessarily share the same vision of how to preside over the EU) and followed unsuccessful presidencies of other Central and East European states (which increased the pressure for success).

The above-mentioned dilemmas and challenges related to the presidency were focused on the area of its priorities. Their number, content, and 
form had been worked out long before the Polish presidency started. In many respects, they were implemented under circumstances different than originally expected. As a consequence, they were adapted on account of the sudden political and economic changes in the environment.

The purpose of the present study is to show Poland's presidency of the EU Council through its priorities. The circumstances of their formulation, selection and implementation will be analyzed. Therefore, the research questions concern the factors that contributed to the selection of Poland's priorities, the issues of what selection methods were applied and what national agenda was 'concealed' in Community rhetoric. As concerns the first issue, the authors plot the political and legal path taken when defining the priorities. In the case of the second, they show the EU's agenda, Polish ambitions and the context of the trio. The third issue is illustrated by presenting the priorities, with emphasis placed on the pivotal ones. The last issue to be discussed in this paper concerns a debate on assessing the degree of achievement of the priorities.

\section{Preparatory work on the development and implementation of the priorities of Poland's presidency of the EU Council}

When defining the priorities of the presidency of the EU Council, the representatives of Poland considered both the progress in a given policy, the so-called institutional agenda, as well as the challenges posed by individual policies, taking into account the circumstances that necessitated the need to commence activity in the European forum, the current situation on the international and European political stage and the political climate in member states to undertake joint responsibilities. Among the significant elements in the choice of the fields of particular interest for Poland were its interests and goals, as well as the interests of the remaining states of the trio.

Preparatory work towards the Polish presidency started as early as 2008. One of the symbolic first steps involved the appointment of the Government Plenipotentiary for the Preparation of Government Administration Bodies and the Polish Presidency of the Council of the European Union, Mikołaj Dowgielewicz. On January 13, 2009, the Polish Council of Ministers adopted the document Program of Poland's preparation for assuming and administering the presidency of the EU Council submitted by the Government Plenipotentiary for the Preparation of Government 
Administration Bodies and the Polish Presidency of the Council of the European Union. The program stipulated the basis for the activities aimed at the preparation for Poland's presidency, defined the necessary tasks to be performed by public administration in the fields of logistics, human resource management, promotion, and determined the agenda.

It should be pointed out that in the course of these preparatory tasks they were monitored and reported on at the European Committee of the Council of Ministers. The European Union Affairs Committee of the Senate of the Republic of Poland and the Bureau of European Union Affairs Committee of the Sejm were also being notified about the current state of preparations for Poland's presidency of the EU Council and about Poland's participation in the work of the European Union. A key issue ensuring the implementation of the presidency tasks was to provide appropriate financing and an efficient organizational structure. On June 23, 2009, the Council of Ministers passed a resolution on the adoption of the program, entitled Preparation, implementation and administration of the Polish Presidency of the EU Council in the second half of 2011.

A package of program documents concerning the methodology of selecting priorities and the program of activities during the presidency was adopted by the European Committee of the Council of Ministers on July 21, 2009. Precisely a year later, the Council of Ministers adopted the Preliminary list of priorities of the Polish Presidency of the EU Council in the second half of 2011, submitted by the Government Plenipotentiary for the Preparation of Government Administration Bodies and the Polish Presidency of the Council of the European Union. On October 16, 2009, there was a meeting with experts from an advisory group, appointed by the Government Plenipotentiary, on May 5, 2009. They assessed the circumstances of the Polish presidency and recommended its potential priorities and activities. The proposed Polish priorities were presented to and adopted by the European Committee of the Council of Ministers on October 16, 2009 and recommended for review by the Council of Ministers.

Later on, the six priorities adopted underwent transformations on account of the altered European and global circumstances. Eventually, on March 15, 2011, three pivotal priorities of the Polish presidency were announced: (1) European integration as a source of growth, (2) a secure Europe, and (3) a Europe benefiting from openness. They were determined in a process based on a mechanism of consultations held at domestic level, the level of the Poland-Denmark-Cyprus trio, and the level of other member states and EU institutions. 


\section{European integration as a source of growth}

It was not a coincidence that the first priority of the Polish presidency was "European integration as a source of growth." Even the introductory part of the Program of the presidency declared at the beginning that "the European Union is changing at a pace and scope not seen for a long time. The economic crisis - the underlying cause of these changes - has also demonstrated the strengths of European integration. By pulling together, Europe has overcome the shock wave of the crisis" (Ministry of Foreign Affairs, 2011). The introduction referred in practice to two elements: indicating the economic crisis as the main challenge facing the presidency, and identifying European unity and further integration as the way to overcome the crisis. It was stated that "Polish activity in the internal market could be focused, among other things, on the implementation of the European Commission's proposals following from Monti's Report on the future of the internal market, financial sector regulations, mobility and free flow of know-how and innovation, as well as the removal of barriers in the internal Community trade."

It should be mentioned, however, that - apart from energy and budget matters - economic issues were not among Poland's strategic goals. They were rather a result of a thought-out strategy to combine the EU agenda and national preferences. These two, says Magdalena Kałużyńska (2009), provide for the 'attractiveness' of a priority which is in practice related to 'inheriting' the most significant areas of interest from earlier presidencies. Still, the new topics to be selected need to be achievable.

Analyzing the official expansion of the priorities it can be noted that the elements that provided their content were primarily provided by the post-2013 Multiannual Financial Framework, developing the Common Market and Europe's intellectual capital. The Multiannual Financial Framework constituted an element of the EU agenda following from the requirement to develop the EU's financial framework for 2014-2020 as well as the Europe 2020 strategy. The agenda of the European Commission for 2011, which was based on the latter, demonstrated the conviction that it was utterly necessary to counteract the crisis while paying attention to the matters of social justice and security. The focal issue here was the necessity to employ the potential of the Single Market for the needs of economic growth (KOM, 2010).

Polish national interest obviously involved obtaining the largest possible budget that would allow the transfer of resources within structural and 
regional policies to be made, thereby ensuring further dynamic development of the country (Sosnowski, 2009). This approach was coupled with a belief that it was necessary to maintain the current system for financing agriculture. In this sense, the program converged with proposals of the European Commission, which perceived maintaining a large Community budget as the means to stimulate economic development and overcome the crisis.

The Single Market accounted for the second dimension of the priority. The EU agenda strongly emphasized this field, especially as concerns the Services Directive. In 2011 and 2012, the Commission planned to examine the actual dimension of the Single Market with respect to services. By the end of 2011, the implementation of respective directives, in particular as regards the barriers to the development of cross-border services, was to be assessed. These endeavors, among other things, resulted in the drafting of the Single Market Act outlining a range of Commission's proposals on further development of the Single Market of services, development of cross - border online trade, strengthened protection of intellectual property (by virtue of the European Union's patent, not to mention other measures) and many other things (Betka, 2011).

Prior to its presidency, Poland supported the initiatives furthering the Single Market, and perceived it to be a generator of significant benefits for Poland and the Polish economy. It allowed Poland to benefit from existing advantages, in particular as concerns price and salary disparities (Jańczak, 2011). Polish interests converged with social expectations here, as $43 \%$ of Poles believed that the Polish government should stress the economic dimension of integration (Pilecka, 2009). It should also be mentioned that proposed activities in the field of interstate negotiations won support, resulting, among other things, in the declaration to promote economic growth and the Single Market, signed by the leaders of nine EU member states (Great Britain, the Netherlands, Sweden, Finland, Estonia, Lithuania, Latvia, Denmark and Poland) in March 2011.

In December 2011, in his assessment of the implementation of the priority concerned Minister for European Affairs, Mikołaj Dowgielewicz (2011a), stressed those elements that had been achieved. He included among them the "adoption of the 'six-pack', strengthening financial discipline in the EU and eurozone [and] starting the negotiations on a new multi-annual EU budget 2014-2020 with the initial proposal of the European Commission of June [2011]." 


\section{The priority of a secure Europe}

A number of various areas were encompassed within the priority of “A secure Europe," including energy strategy, food security in agricultural policy, protection of external borders and the common policy of security and defense. The financial crisis strongly affected the eurozone during the Polish presidency. It was a significant issue for the EU that continued to be stressed throughout the presidency to provide secure economic governance within the framework of macroeconomic security. Strengthened economic governance in the European Union was to apply both to the economic and financial dimensions. The Polish presidency was a period of initiatives and activities taken in order to improve the regulation and supervision of member states' financial markets and develop the principles of crisis management. Being outside the eurozone, and to a large extent not suffering from the crisis, Poland found it highly difficult to perform its tasks. It became its goal to act as a broker of the 'six-pack', its endeavors were concentrated on preventing divisions between Union states, and maintaining Poland's influence on decisions, as illustrated by the metaphor that "Poland [had] its foot in the door, so as not to let it close and separate states." Importantly, Poland's options were limited, because despite his formal presidency over the EU Economic and Financial Affairs Council, Polish Finance Minister Jacek Rostowski was not invited to the meetings of ministers of the Eurogroup. It should be emphasized that Poland did not play first fiddle in the matters of crisis management security. Given the economic crisis, the primary role in the debate was played by European institutions, led by the duo of the presidents of the European Commission and European Council, and the French-German tandem. Poland's role was limited to organizing numerous important meetings and administering their agendas.

Poland put the matters of energy security in second position, working towards a single energy market. Despite its attempts, Poland failed to pick up the baton of negotiations, thus ensuring more favorable prices of energy resources, in particular of gas and oil, in the future. The issues of the Nord Stream and South Stream pipelines set the tone for negotiations in this field. The construction of the Nord Stream, running directly from the Russian Federation to Germany and bypassing Poland and the Baltic states, significantly infringed on the interests of Poland, which consequently deemed it to be a breach of the EU's solidarity principle. Additionally, Polish energy demands included in the premises of the Strategy 
2020 clashed with the requirement to implement the obligations resulting from the climate summit, which demanded that emissions of $\mathrm{CO}_{2}$ be reduced by $20 \%$ by 2020 . Holding the presidency, Poland stressed its position that environmental goals should be implemented taking into account the socio-economic diversification of various EU member states. The Polish attitude to environmental responsibility, a significant element of which was consideration for economic interests and the needs of industrial sectors in various states, was not approved of by the successor of the presidency, Denmark, among others. It is worth emphasizing that, as concerns climate change, Poland's presidency succeeded in working out a compromise and establishing the EU's negotiating position for the climate conference in Durban. Poland deemed it important that the commitment period of the Kyoto Protocol be prolonged, thus providing for the obligations to continue after 2012. Energy matters were divided into internal and external ones. The aspects of external energy policy and a new energy strategy were discussed at an informal meeting of EU ministers for energy held in Wrocław on September 19-20, followed by the formulation and adoption of the conclusions by the Energy Council on November 24. The internal dimension concerned progress in the matters of the infrastructure package and the acts on energy efficiency. Another significant issue concerned draft regulations on the safety of offshore oil and gas extraction, developed in response to the catastrophe on an oil rig in the Gulf of Mexico in 2010.

In terms of secure Europe, Poland committed itself to the issue of ensuring food security. Assuming that the priority was to promote Poland as a state whose agricultural sector is of high importance for future socio-economic development, Poland continued its activity in the EU aimed at aligning agricultural subsidies in all EU countries and establishing a fishing quota. Introducing the Polish scenario of a single market of food was to increase the competitiveness of agricultural production, resulting in the long-term alignment of food prices in the EU.

The events taking place in North Africa clearly changed Poland's attitude to the implementation of security principles as regards immigration policies (Kaczyński, 2011). The border crisis in Lampedusa, caused by waves of refugees, showed the need for a revision of the common migration policy. This led to a vivid discussion on the amendments to the Schengen Agreement, admitting a temporary reinstatement of checks at EU internal borders. New migration principles resulted in changed operating principles of the European Agency for the Management of Operational 
Cooperation at the External Borders FRONTEX, the only agency with its headquarters in Poland (Warsaw). Poland was not directly affected by the problem of mass refugees, resulting in the Polish presidency promoting the greatest possible openness of borders.

During its presidency, Poland reintroduced the significant issues of the further advancement of a common security policy and of defense to the agenda. In the latter, the Polish presidency wanted to contribute to strengthening the civilian and military potential of the EU and to take action to consolidate direct dialogue between the European Union and NATO. From the time of French presidency in 2008, no other state was so seriously committed to strengthening European responsibility for matters of common defense. To a large extent, our European partners' interest in these issues was positively affected by the events in Libya, which once again revealed the weakness of the EU's ability to become involved. It is worth noting here that Polish Minister of Foreign Affairs Radosław Sikorski was the first EU politician to pay a visit to Libya after Gaddafi was overthrown. After the Lisbon Treaty, Poland's political role was significantly limited in institutional terms. Designing the framework of its presidency's priority, Poland applied three dimensions of international collaboration: that of Weimar, Visegrad and NATO (Niedźwiedzki, 2013). These three dimensions of collaboration provided a foundation for the presidency to operate on. Polish endeavors to implement the assumptions of this priority had occurred long before, though. They can be symbolized by the letter of the Weimar Triangle ministers of foreign affairs and ministers of defense on the common policy of security and defense which was inspired by Poland and sent to Catherine Ashton on December 6, 2010. This was an expression of concern about the sluggish implementation of the provisions of the Lisbon Treaty with regard to this policy. The authors of the letter stressed the need for closer relations between the EU and NATO, the strengthening of planning structures of European operations and increased potential to defend EU territory (Przybylska-Maszner, 2011).

In his speech delivered on March 7, 2011 at the National Defense University in Rembertów, Polish Minister of National Defense Bogdan Klich presented four priorities of his Ministry within the area of the policy of security and defense during the Polish presidency. They included bolstering the EU's military capacities, improving the coordination of EU's civilian and military capacities, EU-NATO relations, and increased collaboration with Eastern partners. The fundamental assumption in the area of bolster- 
ing the EU's military capacities referred to implementing the Pooling $\&$ Sharing project, which was supported by the European Defense Agency and European External Action Service. It should be observed that the adverse economic situation was conducive to the debate on cuts to be made in defense expenditure. Another important Polish initiative was launching battlegroups. The groups that were set up had combat duties but have not been used so far. Poland promoted the concept of using battlegroups as a rapid reaction force that enters a territory suffering from crisis (Initial Entry Force). The field of improving the coordination of EU's civilian and military capacities assumed reforming the command structure, in particular improving the ability to plan and conduct operations at strategic level, and aligning civil-military cooperation. The alignment of EU-NATO cooperation concerned agreed projects, including ones related to combating improvised explosive devices and providing medical support.

The Polish presidency was also challenged with the task of launching the Crisis Management and Planning Directorate responsible for crisis management within the strategic planning of EU civilian and military operations, and participating in developing a Common Security and Defense Policy. Poland called for the establishment of a standing EU operations centre in charge of planning and conducting military operations. Civilian-military cooperation in the field is decisive for the efficiency of an operations centre, which can be deemed an element of the potential to plan and conduct military operations. An EU operations centre would facilitate cooperation with NATO without infringing on the autonomous decisions of either organization. This standing HQ was not set up during the Polish presidency, but a solution was found to establish the EU Operations Center for the Horn of Africa. The area of EU-NATO relations assumed strengthening practical cooperation between the two organizations. Its foundation was to be provided by an agreement of cooperation between the EU and NATO in the area of military operations conducted by both organizations. Poland also assumed that member states of the Eastern Partnership would intensify their participation in EU operations by signing an agreement to this effect. The culmination of these initiatives, that decided their future, occurred at the October summit that dealt with the issues of a common policy of security and defense. On account of the specific nature of this topic it should be deemed that the Polish presidency concluded the essential stage of political discussions and laid the foundations for the subsequent stage of implementation of various initiatives. From the point of view of Polish interests, it is worth mentioning that the projects submit- 
ted by the European Defense Agency, Poland's declaration of participation in the project to supervise marine territories and to draw up a project for a European Satellite Communications Procurement Cell (ESCPC) was received with interest. The first general assessment of Poland's activity was made at a session of the EU Foreign Affairs Council, held on December 1. A number of Polish initiatives were not completed during the period of the presidency and their outcomes were (or in some cases still are) expected in the years to come.

\section{Europe benefiting from openness}

The last of the official priorities of the Polish presidency concerned "Europe benefiting from openness." From the beginning, the Program of the presidency declared that "the well-being of EU societies depends not only on the internal situation but also on relations with third countries, and the situation outside the European Union. The Polish Presidency will support the EU foreign and security policy aimed at enhancing the EU's international position" (Ministry of Foreign Affairs, 2011, p. 10). The goal was defined as furtherance of the domination of European regulations and values in new territories. This was to be achieved by means of further enlargements, neighborhood cooperation and European activity on a global scale. The emphasis, however, was put on the development of the Eastern Partnership which was justified with both political (stabilization) and economic (free trade) arguments. The events of the Arab Spring compelled the presidency to refer in its plans to the events in North Africa, which found expression in referring to 'Southern neighbors' as significant partners. Yet, the focus of Poland's interest was on Eastern states of Ukraine, Belarus, Moldova, Georgia, Armenia and Azerbaijan. The operating goal defined in the Program involved the signing of association agreements, which was to be achieved at the Summit of the Partnership and Civil Society Forum. Separate reference was made to Belarus, as a partner that requires special attention, and Tunisia, Egypt and Libya with whom the presidency planned "to initiate cooperation based on partnership, focused on supporting democratic transformations, building modern state structures [and] economic growth" (Ministry of Foreign Affairs, 2011, p. 11). Further enlargement was also deemed to be a significant element of the priority and described as a 'strategic political project'. On the one hand there was a goal of signing the Accession Treaty with Croatia and taking 
further steps towards the accession of Turkey, Iceland and the Western Balkans. On the other, there was a more general declaration that "[the] Presidency will strive to ensure that the enlargement strategy moves forward" (Ministry of Foreign Affairs, 2011, p. 11).

Ironically, Croatian accession was not a priority in terms of Polish interests and the signing of the Accession Treaty on December 9, 2011 followed from an earlier agenda. Thus the event did not have critical importance attached to it, in contrast with the Association Agreements to be signed with the Eastern Partnership, in particular with Ukraine. They were to be a measure of the presidency's success in terms of its third priority and the efficient implementation of the national interest while administering the EU. Additionally, in contrast to Western politicians, their Polish peers perceived association as the first step towards full membership of the Partnership states. The failure to formally enter an Association Agreement with Ukraine, however, made Croatia the only tangible success of the openness/enlargement policy. Consequently, the admission of Croatia as an EU member was announced as a success of Poland.

The emphasis placed on the issues of the Eastern Partnership called for 'balancing' it with adequate concern for our Southern neighbors, as well as Russia, and dealing with the issues of Community interests alongside national ones. Therefore, the Program of the presidency announced the development of the EU-Russian Partnership for Modernization. Additionally, it made a brief reference to the negotiations within the WTO, which were to culminate at a conference to be held in December 2011. In a similar vein, the need to develop a single, coherent EU position in the forum of the United Nations, G20, etc. was stressed.

The Eastern Partnership, which was initiated by Poland, was brought to life at the summit of the Council of the European Union in March 2009 during the Czech presidency. The outcome of this decision was the first Partnership Summit in May of the same year. The second summit initially was to be held in Budapest in May 2011 under the Hungarian presidency. Eventually, the summit was postponed due to a meeting of G20 states' leaders planned in Deauville at the same time, and the situation in North Africa (Jańczak, Przybylska, 2011).

It is worth noting that in terms of national interest, the support for EU Eastern neighbors (including their integration efforts) enjoyed a favorable reception both among ordinary Poles and the political elite, and this was so over a considerable time. It should be remembered that the idea of the Eastern Dimension was presented in 2003 by the Polish Minister of For- 
eign Affairs Włodzimierz Cimoszewicz (Jańczak, 2010), to reappear in 2008 as a Polish-Swedish initiative (Wojna, Gniazdowski, 2009).

The second summit of the Eastern Partnership was eventually organized in Warsaw on September 29-30, 2011. The declaration adopted by the summit indicated that " $\mathrm{t}]$ he Eastern Partnership aims to create the necessary conditions to accelerate political association and further economic integration between the European Union and interested partner countries, recognising the economic benefits of enhancing trade in goods and services." The summit declared the strengthening of financial support and emphasized the role of visa-free regimes between the EU and countries of the Partnership. The summit brought together representatives of member states (including German Chancellor Angela Merkel, French Prime Minister Francois Fillon and Spanish Prime Minister Jose Zapatero), Partnership states (President of Armenia Serge Sarkissian, President of Azerbaijan Ilham Aliyev, President of Georgia Mikheil Saakashvili, President of Ukraine Viktor Yanukovych and Prime Minister of Moldova Vlad Filat), and the leaders of EU institutions (including among others European Council President Herman Van Rompuy, European Parliament President Jerzy Buzek and European Commission President Jose Manuel Barroso). Belarus boycotted the summit, thereby becoming an important element of the debate. The summit also produced a declaration supporting civil society in the countries of the Partnership by means of the Civil Society Facility, and to further democratization, mainly applying the European Endowment for Democracy. The summit also revealed critical assessments of Ukraine and its standards of human rights protection, symbolically embodied by the imprisoned Yulia Tymoshenko. On November 28-30, 2011, the Eastern Partnership Civil Society Forum was held in Poznań, bringing together the representatives of Non-Government Organizations from the Partnership states.

The attention of international opinion was distracted from the 'Eastern issue' of the priority in question by the events in North Africa and the Middle East. In the opinion of some scholars "the region of the Middle East and North Africa had a marginal role in the Polish foreign policy, it was gaining importance only temporally, in case of conflicts" (Sasnal, 2011, pp. 9-10). Yet, even the EU itself did not respond in an unequivocal manner in the first half of 2011 (Jańczak, 2011). At that time Polish Foreign Ministry sent a mission to the region, including the legendary Solidarity leader and former president, Lech Wałęsa, the Senate speaker and former Solidarity oppositionist, Bogdan Borusewicz and finally Polish Foreign 
Minister Radosław Sikorski, just two weeks before the Polish presidency started (Sasnal, 2011, p. 11).

Said events relatively quickly resulted in the priority referring to the situation in the region. This evidenced the efficiency of the Polish presidency corps and signified the attitude of Poland which in the name of European solidarity was able to take into account a territory where she had no direct interests.

In his assessment of the Polish presidency, upon its completion, Polish Minister for European Affairs Mikołaj Dowgielewicz stated that "Poland adequately fulfilled the role of the state that endeavors to keep the door to the EU open" and that "several ideas [Poland] injected in the circulatory system of the EU, such as the European Endowment for Democracy or opening the Eastern Partnership to new initiatives shall be continued" (Dowgielewicz, 2011b). While the promotion of the enlargement idea was deemed successful (although in the opinion of many commentators it lacked concrete proposals for the Partnership members [Jańczak, Przybylska-Maszner, 2012]) the lack of agreement on the accession of Bulgaria and Romania to the Schengen zone can be viewed as a failure of Poland with respect to EU openness.

\section{Conclusions}

The 184 days of Poland's presidency of the Council of the European Union were a period of forming a new practice to administer the presidency on the basis of the regulations introduced by the Lisbon Treaty. Poland was yet another country that needed to create and consolidate the operating practice of a new network of inter-institutional relations. To a large extent, Poland completed the adaptation of the ambiguous provisions of the Treaty to Brussels practice based on the implementation of legal regulations alongside numerous informal principles. Organizational changes that followed from the new division of powers influenced the fulfillment of the presidency's tasks curbing them significantly. The informal side of political debate and the opportunity to promote Poland as a Central and East European state that has become a European broker, benefited from those changes, though.

The President of the European Parliament, Jerzy Buzek, indicated that Poland is, in the EU, "synonymous with positive energy, enthusiasm and faith in the future. It is a great asset at the start of the Polish presidency 
[...]. It will be an important task for Poland to change the mood in the EU" (Buzek, 2011). The European context of the presidency influenced its course, making the agenda of the meetings quite difficult. The Polish presidency was overshadowed by the economic crisis in Southern European states, instability in the eurozone, riots in Greece and the events in North Africa. Despite earlier concerns, the context provided by the internal situation of the state holding the presidency, which could have disturbed it (as was the case of Hungary) was conducive to the achievement of the goals. Political efforts aimed at promoting the position of Poland in Europe were surprisingly unified. The activity conducted within the framework of all the priorities was influenced by the approaching parliamentary elections. Political mobilization, however, did not sway the stability of the political situation in Poland and the relative unity in creating postulates and presenting them to European partners.

The statistics of the Polish presidency are as follows: 452 meetings, including 20 informal meetings of the EU Council and EU ministerial meetings, 30 conferences at ministerial level, and over 300 expert meetings (Niklewicz, 2013). Poland was visited by approximately 30,000 delegates who came for presidency-related meetings and 2,150 accredited journalists. Around 1,200 persons were directly involved in the activities of the Polish presidency. It was accompanied by an extensive cultural offer. This organizational momentum only marginally translated into the implementation of the priorities of the presidency. It worth mentioning the twofold character of the objectives of the Polish presidency, which was to contribute to the achievement of 'the priorities of the Polish presidency' stipulated in the Program and resulting in most cases from the agenda of the EU, and the implementation of the 'Polish priorities', the primary one being the promotion of Poland as a state which can effectively influence the European stage, is a good organizer and host. The issue of Polish interests woven into the Program of the presidency slipped into the background.

Poland, a debutant in the role of presidency leader, had a limited impact on the achievement of the priorities of the Polish presidency. However, it is worth mentioning a few issues that could be considered a political success of its activity in that period: the return to the main agenda of the EU's Eastern themes (regardless of the dominant events in North Africa), the emphasis on the role of Ukraine and Belarus on the European stage, and first and foremost the enhanced knowledge and awareness that is necessary to approach these states; adoption of the 'six-pack', 
and the conclusion of legislative work on a European patent. Additionally, the proposal to deepen integration (whether by means of such concrete instruments as continued development of the Single Market or by a strong political impulse present during the Polish presidency) as a cure to overcome the (economic and political) crisis appears to remain as a strong mark of the Polish presidency.

A number of initiatives that were concluded or significantly advanced during the Polish presidency had been initiated several months or years before. The Polish presidency clearly marked the end of efforts aimed at Croatian accession to the EU and the efficient launch of the Eastern policy. On the one hand "the events in North Africa postponed the [Polish] priority that has been the Eastern Partnership." Yet, adopting a constructive attitude, the Polish presidency managed to demonstrate its commitment to matters important for other member states, thereby strengthening the European Neighborhood Policy and, by extension, the Eastern Partnership (Kucharczyk, Łada, 2011). Importantly, during the Polish presidency a debate on the next stage of the transformation of the common security and defense policy started.

In his speech to the European Parliament summarizing the presidency, Polish Prime Minister Donald Tusk observed: "although we were a debuting country, or maybe because we were, our presidency was the presidency of people committed to perform their tasks, European tasks, as well as they could" (Tusk, 2011). Polish commitment translated into the organizational and promotional success of Poland. The successful implementation of the presidency's priorities aligned with European agenda, as well as the area of unrealized goals, provided a background for the activity of Polish diplomacy, verifying and confronting its potential with the practice of operating in the European arena. Efficiency, effectiveness and adequate collaboration between various institutions are three notable qualities of the Polish presidency.

The success of the Polish presidency can also be sought in the domestic arena. EU issues were vividly covered in the Polish media. There were many new initiatives aimed at propagating the knowledge of functioning EU institutions and Poland's ambitions in the European arena. Not only government representatives and political actors, but also local governments and NGOs showed their commitment. As the awareness of the EU's importance grows, so does the interest in Polish matters discussed in decision-making circles. This may change the attitude of Poles to potential forms of participation in the supranational dimension. 


\section{References}

Betka T. (2011), Komisja chce pogłębienia jednolitego rynku ustug [Commission wants to develop a common service market], www.uniaeuropejska.org, 20.03.2011.

Buzek J. (2011), Przesłanie przewodniczqcego Parlamentu Europejskiego Jerzego Buzka na posiedzenie Zgromadzenia Narodowego z okazji rozpoczęcia polskiej prezydencji w Radzie Unii Europejskiej [Speach of Jerzy Buzek - the President of The EU Parliament during the session of the Polish Parliament on a day of the beginning the Polish EU Council presidency], July 1, Warszawa.

Dowgielewicz M. (2011a), Korekta priorytetów polskiej prezydencji w UE nie jest konieczna [A correction of the Polish EU presidency's priorities is not necessary], "Gazeta Prawna”, March 11.

Dowgielewicz M. (2011b), Dowgielewicz podsumowuje polska prezydencję: jesteśmy zadowoleni [Dowgielewicz summarizes Polish presidency: we are satisfied], 27.12, http:/www.europarlament.pap.pl/palio/html.run_Instance=cms_ep.pap.pl\&_PageID=1\&_menuId=17\&_nrDep=29530\&_CheckSum=-1300046553, 3.05.2012.

Jańczak J. (2011), Rynek wewnętrzny jako obszar priorytetowy polskiej prezydencji [Internal market as one of the priorities of the Polish presidency], in: Priorytety prezydencji Polski w Radzie Unii Europejskiej [Priorities of the Polish EU Council presidency], eds. Z. Czachór, T. R. Szymczyński, Wydawnictwo Naukowe PWN, Poznań, pp. 113-135.

Jańczak J., Przybylska-Maszner B. (2011), Partnerstwo Wschodnie w ramach polityki wschodniej kluczowym priorytetem polskiej prezydencji [Eastern Partnership within Eastern policy as a key priority of the Polish presidency], in: Priorytety prezydencji Polski w Radzie Unii Europejskiej [Priorities of the Polish EU Council presidency], eds. Z. Czachór, T. R. Szymczyński, Wydawnictwo Naukowe PWN, Poznań, pp. 137-168.

Jańczak J. (2010), Efektywność proponowania i wdrażania Partnerstwa Wschodniego przez Polskę wewnatrz Unii Europejskiej [Effectiveness of tendering and implementing Eastern Partnership vy Poland in the EU], in: Partnerstwo Wschodnie. Wymiary realnej integracji [Eastern Partnership. Dimensions of real integration], eds. M. Zdanowicz, T. Dubowski, A. Piekutowska, Oficyna Wydawnicza ASPRA-JR, Warszawa, pp. 85-97.

Jańczak J., Przybylska-Maszner B. (2012), Polen regierte Europa. Das Beispeil Oestliche Partnerschaft, "Welt Trends. Zeitschrift für internationale Politik", no. 85, pp. 91-98.

Jańczak J. (2011), Polish Presidency of the European Union and the Arab Spring, in: The Arab Spring, ed. B. Przybylska-Maszner, Wydawnictwo Naukowe WNPiD UAM, Poznań, pp. 135-146.

Kaczyński P. M. (2011), Polish Council Presidency 2011, Swedish Institute for European Policy Studies, Stockholm. 
Kałużyńska M. (2009), Polska prezydencja w Unii Europejskiej-jak pomyślnie zdać europejski egzamin dojrzałości? [Polish EU presidency - how to pass European mature exam?], in: Prezydencja Polski w Unii Europejskiej- 2011 r. [Poland's EU presidency - 2011], ed. K. Smyk, Urząd Komitetu Integracji Europejskiej, "Biuletyn Analiz", no. 22, pp. 4-11.

KOM (2010), Note of the Commission to the European Parliament, Council, the Economic and Social European Committee, and Regions Committee - "Program of the Commission for 2011”, 623 final version, vol. 1, Brussels, October 27.

Kucharczyk J., Łada A. (2011), To nie był spokojny rejs: Sześć miesięcy polskiej prezydencji $w$ Radzie UE [It was not a peaceful cruise: six months of the Polish EU Council presidency], "Gazeta Wyborcza”, December 15.

Ministry of the Foreign Affairs (2011), Program of the Polish Presidency of the Council of the European Union. 1 July 2011-31 December 2011, Warsaw.

Niedźwiedzki A. (2013), Przewodnictwo Polski w Radzie UE w 2011 r. Część I - Aspekty prawno-instytucjonalne [Poland's EU Council presidency in 2011. Part I - Legal and institutional aspects], http://www.psz.pl/index.php?option $=$ com_content\&task=view\&id=38773, 1.03.2013.

Niklewicz K. (2013), Pót roku prezydencji w liczbach [Half of the year of presidency in numbers], http://p12011.eu/content/pol-roku-prezydencji-w-liczbach, 1.03.2013.

Pilecka M. (2009), Postawy prounijne oraz oczekiwania społeczne wobec UE $w$ kontekście przyszłej prezydencji Polski, in: Prezydencja Polski w Unii Europejskiej - 2011 r. [Poland's EU presidency - 2011], ed. K. Smyk, Urząd Komitetu Integracji Europejskiej, “Biuletyn Analiz”, no. 22, pp. 130-148.

Przybylska-Maszner B. (2011), Polska prezydencja w obszarze Wspólnej Polityki Bezpieczeństwa i Obrony. Uwarunkowania, mechanizm działania, założenia [Polish presidency on Common Security and Defence Policy. Determinants, mechanism of action and assumptions], in: Priorytety polskiego przewodnictwa w Radzie Unii Europejskiej [Priorities of the Polish EU Council presidency], eds. Z. Czachór, T. R. Szymczyński, Wydawnictwo Naukowe PWN, Warszawa, pp. 187-230.

Sasnal P. (2011), Bliski Wschód bliższy niż Wschód: Polska wobec arabskiej wiosny ludów [Middle East closer than East: Poland and Arab Spring], "Polski Przegląd Dyplomatyczny", no. 1, pp. 9-16.

Sosnowski Ł. (2009), Negocjacje Perspektywy Finansowej na okres po 2013 r. w kontekście polskiej prezydencji w Radzie UE [Negotiations on Financial Perspective after 2013 and Polish EU Council presidency], Urząd Komitetu Integracji Europejskiej, "Biuletyn Analiz”, no. 22, pp. 63-69.

Tusk D. (2011), Przemówienie premiera Donalda Tuska w Parlamencie Europejskim, podsumowujacym polska prezydencje [Speach of the Prime Minister Donald Tusk in the European Parliament to summarize Polish presidency], http://www.msz.gov.pl/resource/4b0b8e96-105b-4539-87ff-993693a32d3e, 1.03.2013. 
Wojna B., Gniazdowski M. (eds.) (2009), Partnerstwo Wschodnie - raport otwarcia [Eastern Partnership - opening report], Polski Instytut Spraw Międzynarodowych, Warszawa.

\begin{abstract}
The paper discusses the Polish presidency of the EU Council in terms of its priorities. It analyzes the circumstances of their formulation, selection and implementation. The authors answer the question of what influenced the selection of Poland's priorities and what selection mechanisms were applied. Additionally, they examine how the national agenda was 'concealed' in Community rhetoric. Thus, the analytical part discusses the political and legal path that determined the priorities. The EU agenda, Polish ambitions and the context of the trio is also presented. The paper concludes with the authors' assessment of the implementation of the priorities.
\end{abstract}

